\title{
Socio-economic Conditions of Flood Affected People of the Northern Districts of Bangladesh
}

\section{Omar Faruque}

Associate Professor, Department of Accounting, and Information Systems, Begum Rokeya University, Rangpur, BANGLADESH

*Corresponding Contact:

Email: faruque1712@gmail.com

Manuscript Received: 16 August 2021

Accepted: 12 Oct 2021

\begin{abstract}
In 2017, the death toll from floods sweeping in the northern areas of Bangladesh had climbed above 150. In Dinajpur, Rangpur, Lalmonirhat, Kurigram, and Thakurgaon, more than 57.18 lakh people have been affected by the flood, and 6.11 lakh hectares of land is damaged by the floods in 32 districts. Flood is an important natural disaster that deeply destroys the infrastructure and socioeconomic conditions of the area. After the flood, the flood victims feel very unlucky. Their crops are destroyed. They are uncertain about their future. They do not know what will happen tomorrow. This study is conducted to find out the real situations of the flood victims of the said areas. The primary purpose of this study is to provide a review of the socio-economic conditions of floodaffected people of the northern districts in Bangladesh. To develop the paper, primary as well as secondary data is used. The quantitative and qualitative analysis is conducted for the study. Primary data is collected through a set of well-structured questionnaires. To collect the primary data, a personal survey method is used. Computerized modern technology is applied in coding, tabulating, and processing data. The victims are asked for their perceptions towards life. It reveals that no victim is extremely pleased with their life before and after the flood, and 35\% of victims were pleased before the flood, but after the flood, that rate reduced to $8 \%$. On the other hand $5 \%$ of victims were extremely displeased, but after the flood, that increased to $17 \%$. Floods have huge consequences on people, economics, and the environment. Flooding of regions used for socio-economic activities produces a variety of negative effects. The government has various programs for food, housing, medical, and education, but that is not enough. It is very little than the affected people. Providing adequate support for flood-affected people and preventing floodwaters can save the people of the river basin. It also reveals that by solving some problems locally, some nationally, and some internationally, it is possible to fill the lives of flood-affected people with laughter and joy.
\end{abstract}

Keywords: Flood, Socio-economic Conditions, Social Safety Net, Flood Victims

This article is is licensed under a Creative Commons Attribution-NonCommercial 4.0 International License.

Attribution-NonCommercial (CC BY-NC) license lets others remix, tweak, and build upon work non-commercially, and

although the new works must also acknowledge \& be non-commercial. 


\section{INTRODUCTION}

The people of Dinajpur, Rangpur, Lalmonirhat, Kurigram, and Thakurgaon were flooded in 2017. The death toll from floods sweeping the northern areas of Bangladesh has climbed above 150, and in South Asia, it has climbed above 1,000. The flood washed away the seedbeds in many areas, and many seedlings were needed to grow new crops on the damaged 6.11 lakh hectares of land. Many of the flood-hit people could not return home from temporary shelters as their houses were badly damaged.

Flood is an important natural disaster that deeply destroys the infrastructure and socioeconomic conditions of the area (Rahman et al., 2020). The people of the northern region of Bangladesh are in difficulties. After the flood, they feel unlucky. Their crops are destroyed. They are in uncertainty about their future. From all aspects, they are very unhappy. They do not know about their future. They lost everything in flood in August 2017. This research is conducted to find out the real situations of the flood victims of the said areas.

\section{LITERATURE REVIEW}

Nott (2006) studied that a flood event is not considered to be a natural hazard unless there is a threat to human life, and property. The extent of a flood has a direct relationship for the recovery times of crops, pastures, and the social, and economic dislocation impact to populations. Floods are the most cost, and wide reaching of all natural hazards. They are responsible for up to 50,000 deaths, and adversely affect some 75 million people on average worldwide every year. Disease outbreak is common especially in less developed countries. Malaria, and Typhoid outbreak after the floods in tropical countries are also common. It has been estimated that in India and Bangladesh 300 million people live in areas that are affected by floods.

Dixit (2003) pointed out that vulnerability are the condition of a person or group in terms of their capacity to anticipate, cope with, resist, and recover from the impact of a natural hazard. Even in normal times people live in vulnerable conditions. Vulnerable conditions and families find it hardest to reconstruct their livelihood following a disaster.

Ninno (2003) revealed that the 1998 floods in Bangladesh caused severe damage to the rice crop, and threatened the food security of tens of millions of households. Government food transfers to the affected people helped limit the impact of the flood on household access to food. The flood led to major crop losses, losses of other assets, and lower employment opportunities, and thus affected household income as well as market prices.

Sinclair and Pegram (2003) stated that floods cannot be prevented but their devastating effects can be minimized if advance warning of the event is available. With large increase in population, and increasing urbanization (mainly driven by poverty) there are more people living in informal settlements, which are often on flood plains as this is the only undeveloped land available near cities.

Kundzewicz, et al. (2002) argues that floods are natural phenomenon for which the risks of occurrence are likely to continue to grow, increasing levels of exposure, and insufficient capacity among the factors responsible for the rising vulnerability. Water related events such as floods have been a major concern since the dawn of human civilization.

From the reviewed literature, it's clear that the people living along the river banks in the study area has increased over the years, and has made them susceptible to the flooding. The evidence is that flood risk is increasing, and continuing vigilance is needed to ensure 
that existing systems are maintained, and improvements introduced. From the above study, it is said that there is a gap in existing literature. Thus, the present study is designed to overcome the above gap, and add some new findings with its existing literature.

\section{Rationale of the Study}

The people of the northern region of Bangladesh faced a serious flood. The following table shows an unbelievable situation of flood-affected people in 2017.

Table 1: Flood at a glance

\begin{tabular}{|l|l|}
\hline \multicolumn{2}{|c|}{ Flood at a glance } \\
\hline Population affected & 57.18 lakh \\
\hline Families affected & 13.22 lakh \\
\hline People in shelters & 2.97 lakh \\
\hline Crops affected & 6.11 lakh hectares \\
\hline Districts affected & 32 \\
\hline
\end{tabular}

Source: Daily newspaper

Now it is high time to assess the present situation of that flood-affected people. It is time to assess the level of nutrition of the affected population (Faruque, 2021). Food security is to ensure for the people. The affected people have the problem of shelter, health, and education. To give the proper recommendation, it is a must to assess the real situation of the flood-affected people. This study seeks to bring the real situation in flood-affected people, and at the same time to find a recommendation for the betterment of the victim people.

\section{Objectives of the Study}

The objective of the study is to provide a review on socio-economic conditions of floodaffected people of the northern districts in Bangladesh.

The other specific objectives are as follows:

- To analyze the socio-economic conditions of the flood-prone areas of the northern districts in Bangladesh

- To trace out the problems of the study areas.

- $\quad$ To find out the possible measures to minimize the problems.

\section{Methodology OF THE Study}

To develop the paper, primary as well as secondary data are collected. The quantitative, as well as qualitative analysis is conducted. 57.18 lakh people of Bangladesh in the northern region were affected by the flood in August 2017. The flood-affected people of Dinajpur, Rangpur, Lalmonirhat, Kurigram, and Thakurgaon are considered as the population for this study purpose. Among a large number of flood-affected people, 100 flood victims with a convenience sampling method is selected as the sample of this study purpose. Primary data are collected through a set of well-structured questionnaires. To collect the primary data, a personal survey method is used. This process is focused on a group meeting with the various stakeholders. The secondary data is collected from the daily newspaper, economic news, related journals, books, official statistics, published brochures, prospects, and websites. 


\section{Findings AND Discussion}

The collected data shows the socio-economic conditions of flood-affected people of the northern region of Bangladesh. These conditions are evaluated through many separate indicators, like personal security, health, shelter, education, medical facility, number of animals, and crops.

\section{Comparison of personal security for flood victims before and after the flood}

The income per day, savings per day, and the consumption pattern show the basic socioeconomic conditions of the people (Lashari \& Mohyuddin, 2012; Chowdhury, 2016; Khanum, 2013; Karmakar et al., 2018). The income, saving, and consumption pattern of flood victims is an important indicator to assess the socio-economic conditions of flood victims. The following tables show the personal security level of flood victims of the northern region of Bangladesh.

\section{Personal income and savings}

The data shows that before flood only 5\% of flood victims had fallen in below 100 taka income per day, but after the flood this number increased to $25 \%$. Before the flood, the $47 \%$ of people earned taka 200 to 300, but this person is dropped to the lower level, i.e., 100 taka to 200 taka with a percentage of $49 \%$. On the other hand, before the flood, $64 \%$ of people have saved nothing, but after the flood, it increased to $86 \%$.

Table 2: Income per day of flood victims for flood victims before and after the flood

\begin{tabular}{|c|c|c|c|c|}
\hline \multicolumn{5}{|c|}{ Income per day } \\
\hline \multicolumn{2}{|c|}{ Before Flood } & \multicolumn{2}{c|}{ After flood } & \\
\hline Income (Tk.) & Frequency & Income (Tk.) & Frequency & Change (+/-) \\
\hline $00-100$ & 5 & $00-100$ & 25 & -20 \\
\hline $100-200$ & 35 & $100-200$ & 49 & -14 \\
\hline $200-300$ & 47 & $200-300$ & 18 & 29 \\
\hline $300-400$ & 5 & $300-400$ & 4 & 1 \\
\hline $400-500$ & 6 & $400-500$ & 3 & 3 \\
\hline $500-600$ & 2 & $500-600$ & 1 & 1 \\
\hline $600-700$ & 0 & $600-700$ & 0 & 0 \\
\hline$>700$ & 0 & $>700$ & 0 & 0 \\
\hline Total & 100 & Total & 100 & 0 \\
\hline
\end{tabular}

Source: Field Survey

Table 3: Savings per day of flood victims for flood victims before and after the flood

\begin{tabular}{|c|c|c|c|c|}
\hline \multicolumn{5}{|c|}{ Savings per day } \\
\hline \multicolumn{2}{|c|}{ Before Flood } & \multicolumn{2}{c|}{ After flood } & \\
\hline Savings (Tk.) & Frequency & Savings (Tk.) & Frequency & Change (+/-) \\
\hline 0 & 64 & 0 & 86 & -22 \\
\hline $50-100$ & 21 & $50-100$ & 8 & 13 \\
\hline $100-150$ & 8 & $100-150$ & 5 & 3 \\
\hline $150-200$ & 5 & $150-200$ & 1 & 4 \\
\hline $200-250$ & 1 & $200-250$ & 0 & 1 \\
\hline $250-300$ & 1 & $250-300$ & 0 & 1 \\
\hline $300-350$ & 0 & $300-350$ & 0 & 0 \\
\hline
\end{tabular}




\begin{tabular}{|c|c|c|c|c|}
\hline$>350$ & 0 & $>350$ & 0 & 0 \\
\hline & 100 & & 100 & 0 \\
\hline
\end{tabular}

Source: Field Survey

\section{Consumption pattern}

The consumption pattern is one of the most important indicators of identifying the socioeconomic conditions of flood victims. The data shows that before flood, flood victims expensed $80 \%$ of their earnings on inferior goods, but after the flood it increased to $95 \%$, that shows that flood makes bound to the $15 \%$ of more people to expense their earning on the inferior goods consumptions. It indicates that their income reduced at a significant level.

Table 4: Consumption pattern of flood victims for flood victims before and after the flood

\begin{tabular}{|c|c|c|c|c|}
\hline \multicolumn{5}{|c|}{ Consumption pattern } \\
\hline Before Flood & \multicolumn{2}{c|}{ After flood } & \\
\hline Consumption pattern & Frequency & Consumption pattern & Frequency & Change (+/-) \\
\hline Inferior goods & 80 & Inferior goods & 95 & -15 \\
\hline Necessity goods & 18 & Necessity goods & 5 & 13 \\
\hline Luxuries goods & 2 & Luxuries goods & 0 & 2 \\
\hline Total & 100 & Total & 100 & 0 \\
\hline
\end{tabular}

Source: Field Survey

\section{Comparison of Health, Shelter, and Education Facilities for Flood VICTIMS BEFORE AND AFTER THE FLOOD}

Health, shelter, and education are the very important fundamental rights of a human. It should be free for everyone, though it is purchased by the people in most cases. In the following tables, the change of health, shelter, and education facilities are shown.

\section{Health condition}

The health facilities of flood victims are compared with the before and after of the flood. The data shows that before flood, $66 \%$ of flood victims' were extremely dissatisfied with health facilities; but after the flood it increased to $71 \%$. So, there was no doubt, the health facilities of flood victims were reduced.

Table 5: Health condition of flood victims for flood victims before and after the flood

\begin{tabular}{|c|c|c|c|c|}
\hline \multicolumn{5}{|c|}{ Health } \\
\hline Before Flood & \multicolumn{2}{c|}{ After flood } & \\
\hline Indicator & Frequency & Indicator & Frequency & Change (+/-) \\
\hline Extremely Pleased & 0 & Extremely Pleased & 0 & 0 \\
\hline Pleased & 7 & Pleased & 2 & 5 \\
\hline Neutral & 10 & Neutral & 12 & -2 \\
\hline Displeased & 17 & Displeased & 15 & 2 \\
\hline Extremely Displeased & 66 & Extremely Displeased & 71 & -5 \\
\hline Total & 100 & Total & 100 & 0 \\
\hline
\end{tabular}

Source: Field Survey

\section{Shelter satisfaction}

The shelter facilities of flood victims are compared with the before and after of the flood. The data shows that before flood, $48 \%$ of flood victims were extremely dissatisfied with 
shelter facilities; but after the flood it increased to $53 \%$. On the other hand, before flood, $2 \%$ of flood victims were extremely pleased with their shelter facilities; but after the flood it reduced to $0 \%$. So, there is no doubt, the shelter facilities of flood victims reduced.

Table 6: Shelter satisfaction of flood victims for flood victims before and after the flood

\begin{tabular}{|c|c|c|c|c|}
\hline \multicolumn{5}{|c|}{ Shelter } \\
\hline Before Flood & \multicolumn{2}{c|}{ After flood } & \\
\hline Indicator & Frequency & Indicator & Frequency & Change (+/-) \\
\hline Extremely Pleased & 2 & Extremely Pleased & 2 & 0 \\
\hline Pleased & 15 & Pleased & 6 & 9 \\
\hline Neutral & 10 & Neutral & 4 & 6 \\
\hline Displeased & 25 & Displeased & 35 & -10 \\
\hline Extremely Displeased & 48 & Extremely Displeased & 53 & -5 \\
\hline Total & 100 & Total & 100 & 0 \\
\hline
\end{tabular}

Source: Field Survey

\section{Child Education}

In flood-affected areas, it is a common phenomenon that the region is suffering from fewer facilities of education. The flood also reduces the education facilities of these areas. The roads and other physical infrastructure are destroyed by the flood.

The data shows that before flood, $8 \%$ of flood victims were extremely displeased with child education facilities; but after the flood it increased to $13 \%$. On the other hand, before flood, $4 \%$ flood victim people were extremely pleased with their child education facilities; but after the flood it reduced to $3 \%$. So, there is no doubt, the child education facilities of flood victims reduced.

Table 7: Child education satisfaction of flood victims for flood victims before and after the flood

\begin{tabular}{|c|c|c|c|c|}
\hline \multicolumn{5}{|c|}{ Child education } \\
\hline Before Flood & \multicolumn{2}{c|}{ After flood } & \\
\hline Indicator & Frequency & Indicator & Frequency & Change (+/-) \\
\hline Extremely Pleased & 4 & Extremely Pleased & 3 & 1 \\
\hline Pleased & 25 & Pleased & 20 & 5 \\
\hline Neutral & 40 & Neutral & 45 & -5 \\
\hline Displeased & 23 & Displeased & 19 & 4 \\
\hline Extremely Displeased & 8 & Extremely Displeased & 13 & -5 \\
\hline Total & 100 & Total & 100 & 0 \\
\hline
\end{tabular}

Source: Field Survey

\section{Shelter Structure}

Most of shelter of the flood-affected people is made of tin walls with a percentage of 78 . The other shelter structure is made of slums, mud. Only $8 \%$ of shelters are building. But the result after the flood shows a different figure. The slums shelter increases by $28 \%$, and the tin wall house reduced to $45 \%$. So, the result also shows that most of the flood victims lost their shelter, whether partially or fully. 
Table 8: Shelter structure of victims for flood victims before and after the flood

\begin{tabular}{|c|c|c|c|c|}
\hline \multicolumn{5}{|c|}{ Shelter Structure } \\
\hline Before Flood & \multicolumn{2}{c|}{ After flood } & \\
\hline Indicator & Frequency & Indicator & Frequency & Change (+/-) \\
\hline Slums & 5 & Slums & 33 & -28 \\
\hline Mud huts & 7 & Mud huts & 10 & -3 \\
\hline Tin wall house & 78 & Tin wall house & 45 & 33 \\
\hline Building & 8 & Building & 8 & 0 \\
\hline Others & 2 & Others & 4 & -2 \\
\hline Total & 100 & Total & 100 & 0 \\
\hline
\end{tabular}

Source: Field Survey

\section{Animals farming, crops producing, and price of seeds}

Most of the villagers keep animals and produce crops. They live on farming and producing life. The village woman depends on animal farming, like goats and cows. So, it is an important indicator to assess the socio-economic conditions of flood victims. The price of seeds also determines the living standard of flood victims.

\section{Price of seeds}

The data shows that before flood $27 \%$ of people thought that the price of seeds were high, $65 \%$ of people think it was average. On the other hand, after the floods $92 \%$ of victims think that the price of seeds increases. No one thinks that the seed price is decreased.

Table 9: Price of seeds at flood-affected areas before and after the flood

\begin{tabular}{|c|c|c|c|}
\hline \multicolumn{4}{|c|}{ Price of seeds } \\
\hline \multicolumn{2}{|c|}{ Before Flood } & \multicolumn{2}{c|}{ After flood } \\
\hline Indicator & Frequency & Indicator & Frequency \\
\hline High & 27 & Price increased & 92 \\
\hline Low & 8 & Price decreased & 0 \\
\hline Average & 65 & No change & 8 \\
\hline Total & 100 & Total & 100 \\
\hline
\end{tabular}

Source: Field Survey

\section{Livestock}

Livestock is commonly defined as domesticated animals. Farming livestock is an important source of income for the villager (Faruque \& Siddiqua, 2019). They sell the livestock for their survival. Cattle are one of the important livestock in Bangladesh. The flood destroyed the livestock. On the other hand the flood victims sell the cattle in the market. The data shows that $65 \%$ of people hold one to three cattle, but out of these 26 victims sells their cattle for their survival. Before the flood it is shown that only $15 \%$ of victims hold no cattle, but after the flood this percentage increased to $52 \%$.

Table 10: Number of cattle of flood victims before and after the flood

\begin{tabular}{|c|c|c|c|c|}
\hline \multicolumn{4}{|c|}{ Cattle } \\
\hline \multicolumn{2}{|c|}{ Before Flood } & \multicolumn{2}{c|}{ After flood } & \\
\hline Number of cattle & Frequency & Indicator & Frequency & Change (+/-) \\
\hline 0 & 15 & 0 & 52 & -37 \\
\hline
\end{tabular}




\begin{tabular}{|c|c|c|c|c|}
\hline $1-3$ & 65 & $1-3$ & 39 & 26 \\
\hline $3-6$ & 12 & $3-6$ & 6 & 6 \\
\hline $6-9$ & 8 & $6-9$ & 3 & 5 \\
\hline$>9$ & 0 & $>9$ & 0 & 0 \\
\hline Total & 100 & Total & 100 & 0 \\
\hline
\end{tabular}

Source: Field Survey

Farming poultry is another daily work of the village people. For some families it is a hobby. There are two families who held no poultry before the flood, but after the flood it increased to $42 \%$. It indicates that they sold their poultry for their short-term survival.

Table 11: Number of poultry of flood victims before and after the flood

\begin{tabular}{|c|c|c|c|c|}
\hline \multicolumn{5}{|c|}{ Poultry } \\
\hline \multicolumn{2}{|c|}{ Before Flood } & \multicolumn{2}{c|}{ After flood } & \\
\hline Number of Poultry & Frequency & Indicator & Frequency & Change (+/-) \\
\hline 0 & 2 & 0 & 42 & -40 \\
\hline $1-3$ & 18 & $1-3$ & 29 & -11 \\
\hline $3-6$ & 57 & $3-6$ & 19 & 38 \\
\hline $6-9$ & 17 & $6-9$ & 8 & 9 \\
\hline$>9$ & 6 & $>9$ & 2 & 4 \\
\hline Total & 100 & Total & 100 & 0 \\
\hline
\end{tabular}

Source: Field Survey

\section{Damage in flood}

Flood destroyed life, property and crops. Sometimes flood sets an ultimate bad example with its destructive power. In some areas it destroyed extensively. On the other hand it is damaged partially.

\section{Nature of damage of property and crops}

The data shows that $73 \%$ of victims think that their property and crops are damaged parts and rest think that the flood destroyed everything of them.

Table 12: Nature of damage by flood before

\begin{tabular}{|l|c|}
\hline Nature of damage & $\%$ \\
\hline Fully damaged & 27 \\
\hline Partly damaged & 73 \\
\hline Total & 100 \\
\hline
\end{tabular}

Source: Field Survey

\section{Sales of Property}

Table 13: Sales of property at flood-affected areas

\begin{tabular}{|l|c|}
\hline Sales of flood after the flood & $\%$ \\
\hline Land & 5 \\
\hline Other assets & 30 \\
\hline Sales no property & 65 \\
\hline Total & 100 \\
\hline
\end{tabular}

Source: Field Survey 
For survival, the people sell everything of them. In some cases, they sell their land and other important property. The data shows that $5 \%$ of victims sell their land and $30 \%$ of victims sell their other important articles for their existence.

\section{Victims Fallen in Micro-credit}

Micro-credit is an important source of funds for rural people. Though micro-credit facility is too easy to access, it is highly cost. It is also very risky for the borrower. The study shows that $92 \%$ of victims increase their micro-credit from the various loan providers in their region. It indicates that the victims have fallen in high financial pressure.

Table 14: Micro-credit of flood victims

\begin{tabular}{|l|c|}
\hline Increased after flood & 92 \\
\hline Decreased after flood & 0 \\
\hline No change & 8 \\
\hline & 100 \\
\hline
\end{tabular}

Source: Field Survey

\section{Victims' Perception towards the Life}

The victims are asked for their perceptions towards life. It is a very important indicator that no victim is extremely pleased with their life before and after the flood. $35 \%$ of victims were pleased before the flood, but after the flood that reduced to $8 \%$. On the other hand, $5 \%$ of victims were extremely displeased, but after the flood that increased to $17 \%$.

Table 15: Perception towards the life of the flood victims

\begin{tabular}{|l|c|l|c|c|}
\hline \multicolumn{5}{|c|}{ Perception towards life } \\
\hline \multicolumn{2}{|c|}{ After flood } & Frequency & Change (+/-) \\
\hline Indicator & Frequency & Indicator & 0 & 0 \\
\hline Extremely Pleased & 0 & Extremely Pleased & 8 & 27 \\
\hline Pleased & 35 & Pleased & 21 & 21 \\
\hline Neutral & 42 & Neutral & 54 & -36 \\
\hline Displeased & 18 & Displeased & 17 & -12 \\
\hline Extremely Displeased & 5 & Extremely Displeased & 100 & 0 \\
\hline Total & 100 & Total & & \\
\hline
\end{tabular}

Source: Field Survey

\section{Problems of the Flood-Affected Areas}

Floods have huge consequences on people, economics, and the environment. Flooding of regions used for socio-economic activities produces a variety of negative effects. The magnitude of adverse effects depends on the activity, and population vulnerability, and the frequency, severity, and extent of flooding.

- Many people were injured, and animals have died. Many people are homeless. Water supply and electricity were disrupted, and as a result, people were struggling and affected (Faruque \& Rahman, 2021). In addition, floods bring many diseases and infections, including military fever, pneumonic plague, dermatographia, and petrous. Sometimes insects and snakes enter the area and cause a lot of destruction.

- $\quad$ Roads, bridges, farms, homes, and automobiles are destroyed during floods. In addition, the government has deployed firefighters, police, and other emergency equipment to assist victims. They come at the expense of the people and the 
government. Rebuilding the disadvantaged population and getting the business back to normal usually takes a few years.

- In the event of floods, the environment is also affected. Floods do great harm to the environment. Various trace of it has been found in flooded areas. Roads have been broken all around, rivers have collapsed. Floods have caused huge damage to the environment and the environment. The environmental damage caused by a flood takes a long time to overcome.

\section{SUMMARY OF THE FINDINGS}

The research work finds the following findings:

- $\quad$ Before the flood, only 5\% of flood victims had fallen in below 100 takas income per day, but after the flood this number increased to $25 \%$. On the other hand before flood the $47 \%$ of people earned taka 200 to 300 , but these people are dropped to the next lower level, i.e., 100 taka to 200 taka with a percentage of $49 \%$.

- $64 \%$ of people have saved nothing before the flood, but after the flood it increased to $86 \%$.

- $\quad$ Flood victims expensed $80 \%$ of their earnings on inferior goods in before flood, but after the flood it increased to $95 \%$. It indicates that their income reduced at a significant level.

- The health facilities of flood victims are reduced. Before the flood, $66 \%$ of flood victims were extremely dissatisfied with health facilities; but after the flood it increased to $71 \%$.

- $\quad 2 \%$ of flood victims were extremely pleased with their shelter facilities before the flood; but after the flood it reduced to $0 \%$. So, there is no doubt, the shelter facilities of flood victims reduced.

- $\quad$ The data shows that before flood, $4 \%$ of flood victim people were extremely pleased with their child education facilities; but after the flood it reduced to $3 \%$. So, there is no doubt, the child education facilities of flood victims reduced.

- After the flood the slums shelter increased by $28 \%$, and the tin wall house reduced to $45 \%$. So, the result also shows that most of the flood victims lost their shelter, whether partially or fully.

- After the flood, $92 \%$ of victims think that the price of seeds increased. $65 \%$ of people hold one to three cattle, but after the flood, out of these 26 victims sells their cattle for their survival. There were only 2 families who hold no poultry before the flood, but after the flood it increased to $42 \%$.

- $\quad 73 \%$ of victims think that their property and crops are damaged partially and rest thinks that the flood destroyed everything of them. The data also shows that $5 \%$ of victims sell their land and 30\% of victims sell their other important article for their existence, and $92 \%$ of victims' increase their micro-credit from the various loan providers in their region.

- No victim is extremely pleased with their life before and after the flood. $35 \%$ of victims were pleased before the flood, but after the flood that reduced to $8 \%$. On the other hand, $5 \%$ of victims were extremely displeased, but after the flood that increased to $17 \%$. 


\section{SUGgESTIONS}

Floods sometimes take away everything from people. For them, only the ashes of pain remain. Flooded people dream of losing everything, and living a new life. They do not expect help from the government and NGOs. They expect the authority that not to be flooded. This study thinks that there must be some government initiatives to protect people affected by the floods. The government has to do something to reduce the flood, and at the same time, it is necessary to do something so that the people affected by the flood can quickly recover from their loss. The government has various programs for food, housing, medical, and education but that is not enough (Faruque \& Rahman, 2021a). It is very little than the affected people. Providing adequate support for flood-affected people and preventing floodwaters can save the people of the river basin.

\section{Conclusion}

For this study the data is collected through different questionnaires, and most of the respondents may not like it to communicate the information. For the time and budget barriers it was not possible to meet more respondents. The results of this study state that people affected by floods are not good. They also had to lose some of their last assets to deal with the flood to get their food, and shelter. At each indicator of their living standard, they are declined. There are some areas in Bangladesh that are flooded every year. As a result, every year, they have to prepare to fight the floods again to not suffer the loss of the floods. The results of this study, obtained through field observation, give rise to several responsibilities in the long run for flood-affected people. Researchers believe that the sustainable development of the lives of people affected by floods is possible if the results obtained and recommendations are implemented. By solving some problems locally, some nationally, and some internationally, it is possible to fill the lives of flood-affected people with laughter and joy.

\section{REFERENCES}

Chowdhury, M. M. K. (2016). A Theoretical Evaluation of the Socio Economic Influence on the Employees of Bangladesh. Global Disclosure of Economics and Business, 5(2), 85-92. https://doi.org/10.18034/gdeb.v5i2.132

Dixit, A. (2003). Floods and Vulnerability: Need to Rethink Flood Management. Natural Hazard, 28(71), 155-179.

Faruque, O. (2021). The Impact of Labor Mobility on Living Standard: an Empirical Study on the Northern Region of Bangladesh. Global Disclosure of Economics and Business, 10(1), 116. https://doi.org/10.18034/gdeb.v10i1.586

Faruque, O., \& Rahman, M. M. (2021). Development of Small Scale Industry in Rangpur Division of Bangladesh: Employee Perception. Asian Journal of Humanity, Art and Literature, 8(1), 43-54. https://doi.org/10.18034/ajhal.v8i1.572

Faruque, O., \& Rahman, M. M. (2021a). Development of Wholesale and Retail Trade, Repair of Motor Vehicles and Motorcycles Business in Rangpur Division. ABC Journal of Advanced Research, 10(1), 39-56. https://doi.org/10.18034/abcjar.v10i1.569

Faruque, O., \& Siddiqua, A. (2019). Challenges and Opportunities of Grocery Business: A Study on Rangpur City Corporation in Bangladesh. Global Disclosure of Economics and Business, 8(1), 49-60. https://doi.org/10.18034/gdeb.v8i1.97

Karmakar, A., Habib, S. N., \& Ahmed, A. (2018). Socio-Economic Factors Affecting the Perception of Women Entrepreneurs towards Bank Loan: A Study on Rajshahi City. Asian Business Review, 8(3), Art.\#15, pp. 105-114. https://doi.org/10.18034/abr.v8i3.161 
Khanum, R. (2013). Socio-Economic Conditions of Fishermen: Evidence from Hakaluki Haor of Bangladesh. Asian Business Review, 2(2), 77-79. https://doi.org/10.18034/abr.v2i2.106

Kundzewicz, Z.W., Budhakooncharoen, S., Bronstert, A., Hoff, H., Lettenmaier, D., Menzel, L. and Schulze, R. (2002). Coping with variability and change: Floods and droughts. Natural Resources Forum, 26(4), 263-274. https://doi.org/10.1111/1477-8947.00029

Lashari, N. A., \& Mohyuddin, A. (2012). Economic Activities among Barra Community in Sindh, Pakistan: A Case study of Matli Town, District Badin. ABC Journal of Advanced Research, 1(2), 85-93. https://doi.org/10.18034/abcjar.v1i2.9

Ninno, D. C., Dorosh, A. P. and Smith, C. L. (2003). Public Policy, Markets and Household Coping Strategies in Bangladesh: Avoiding a Food Security Crisis Following the 1998 floods. World Development. 31. 1221-1238. https://doi.org/10.1016/S0305-750X(03)00071-8

Nott, J. (2006). Extreme Events: A Physical Reconstruction and Risk Assessment, Cambridge University Press. New York.

Rahman, M. M., Chowdhury, M. R. H. K., Islam, M. A., Tohfa, M. U., Kader, M. A. L., Ahmed, A. A. A., \& Donepudi, P. K. (2020). Relationship between SocioDemographic Characteristics and Job Satisfaction: Evidence from Private Bank Employees. American Journal of Trade and Policy, 7(2), 65-72. https://doi.org/10.18034/ajtp.v7i2.492

Sinclair, S. and Pegram, G., (2003). A Flood Now casting System for the eThekwini Metro, Volume 1: Urgent Now casting using Radar-An Integrated Pilot Study. Water Research Commission (WCR), Silowa Printers South Africa. 